\title{
HCV genotype 4 circulating in the city of Franca, São Paulo State, Brazil
}

Authors

Rejane Maria Tommasini Grotto $^{1}$

Silvia Maria Corvino ${ }^{2}$ Juliana Lara Padovani ${ }^{3}$ Sônia Maria de Coppio Siqueira $^{4}$

Maria Inês de Moura Campos Pardini ${ }^{5}$

${ }^{1} \mathrm{BSPS}, \mathrm{PhD}$ Researcher;

Molecular Biology

Laboratory, Blood

Transfusion Center, Medical

School, Universidade

Estadual Paulista (UNESP),

Brazil

${ }^{2} \mathrm{BS}, \mathrm{MSc}$ Researcher;

Molecular Biology

Laboratory, Blood

Transfusion Center, Medical

School, UNESP, Brazil

${ }^{3} \mathrm{BS}$, MSc Post-graduation

Student; Molecular

Biology Laboratory, Blood

Transfusion Center, Medical

School, UNESP, Brazil

${ }^{4} \mathrm{MD}$, Physician, Santa Casa

de Paraguaçu Paulista,

SP, Brazil

${ }^{5} \mathrm{BS}, \mathrm{PhD}$; Molecular

Biology Laboratory, Blood

Transfusion Center, Medica

School, UNESP, Brazil

Submitted on: 02/11/2011 Approved on: 02/13/2011

Correspondence to:

Rejane Maria Tommasini Grotto

Laboratório de Biologia

Molecular, Divisão

Hemocentro

Faculdade de Medicina,

UNESP

Distrito Rubião Júnior, s/n ${ }^{\circ}$

Botucatu, SP, Brasil

18618-000

regrotto@uol.com.br

Financial Support:

Secretary of Health of

São Paulo State (SESSP),

Brazil and Viral Hepatitis

Program, São Paulo State,

Brazil.

We declare no conflict of interest.
The hepatitis C virus (HCV) genotype distribution worldwide depends on the geographic region $^{1}$ and although genotype 1 is the most prevalent in Brazil, followed by types 3 and 2 , other genotypes have been reported in the country, albeit with a low occurrence rate. ${ }^{2}$ Identification of the viral genotype has epidemiological, clinical and laboratory importance, as it is necessary for therapeutic indication, diagnostic assay target definition and indicates infection progression. ${ }^{3}$

In the city of Franca, in the countryside of São Paulo State, Brazil, one case of hepatitis $\mathrm{C}$ virus genotype 4 (HCV-4) was identified in a 38-year-old male patient from the town of Paraguaçu Paulista, whose HCV infection had been confirmed since 2005. The patient reported the use of intravenous drugs, having been an inmate for several years and having travelled around the state many times. $\mathrm{He}$ was currently living in the city of Franca.

Clinically, the patient had a confirmed case of pulmonary tuberculosis. The patient's circulating virus was genotyped by reverse hybridization and the result disclosed the presence of viral genotype $4 \mathrm{c} / 4 \mathrm{~d}$. This result was confirmed by automated sequencing of the genomic regions 5'UTR, NS5B and core.

The analysis of the regions sequenced through HCV-Blast available at the database The Los Alamos HCV sequence (http://hcv. lanl.gov) confirmed the presence of genotype 4 ; however, the subtyping turned out to be $4 \mathrm{a}$, which was in disagreement with the subtyping obtained through reverse hybridization. Discordant results in genotype 4 subtyping through sequencing and reverse hybridization have been previously reported by Zekri et al. ${ }^{4}$ as well as in other genotypes. ${ }^{5}$

Case reports as the one described here are important to characterize the epidemics and to detect variation in genotype distribution in the country, as well as to promote epide- miological surveillance and acquire information about the virus introduction and transmission routes in the country.

[Braz J Infect Dis 2011;15(3):300]@Elsevier Editora Ltda.

\section{REFERENCES}

1. Simmonds P, Bukh J, Combet $\mathrm{C}$ et al. Consensus Proposals for a Unied System of Nomenclature of Hepatitis C Virus Genotypes. Hepatology 2005; 42(4):962-73.

2. Campiotto S, Pinho LR, Carrilho FJ et al. Geografic distribuition of hepatitis $\mathrm{C}$ virus genotypes in Brazil. Braz J Med Biol Res. 2005; 38(1):41-9.

3. Zhou S, Terrault NA, Ferrell L et al. Severity of liver disease in liver transplantation recipients with hepatitis $\mathrm{C}$ virus infection: relationship to genotype and level of viremia. Hepatology 1996; 24(5):1041-6.

4. Zekri ARN, El-Din HMA, Bahnassy AA et al. TRUGENE Sequencing Versus INNO-LiPA for Sub-Genotyping of HCV Genotype-4. J Med Virol. 2005; 75:412-20.

5. Levada PM, Verdichio-Moraes CF, Corvino SM, Grotto RMT, Silva GF, Pardini MIM. Hibridização reversa e sequenciamento na genotipagem do vírus da hepatite C. Rev Soc Med Trop. 2010; 43(2):135-8. 